\title{
火山灰土凝集剂の凝集・分散特性と \\ 貯水池濁水処理への適用 \\ COAGULATION AND DISPERSION CHARACTERISTICS OF VOLCANIC ASH COAGULANTS AND THEIR APPLICATION TO TURBID WATER TREATMENT IN A RESERVOIR
}

\author{
海野 仁 1 - 小林 幹佳 2 ・箱石 憲昭 ${ }^{3}$ \\ Hitoshi UMINO, Motoyoshi KOBAYASHI and Noriaki HAKOISHI

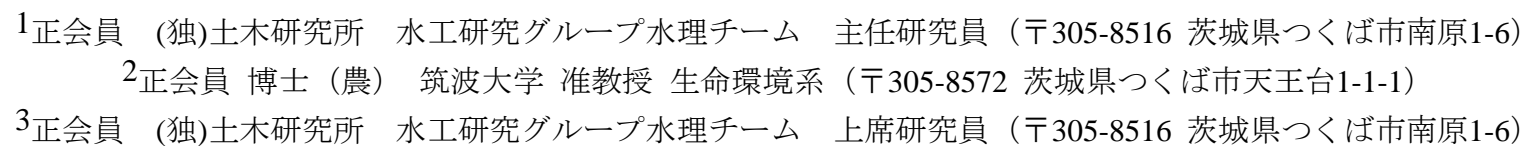

Coagulation treatment is one of countermeasures for turbid water in a reservoir that is brought by lowering of surface level or sediment transport in a reservoir. We have taken volcanic ash coagulants which contain allophane and investigated their coagulation, dispersion characteristics and electrokinetic phenomena. Moreover, we conducted site experiment of coagulation treatment by using volcanic ash coagulants. Through this study, coagulation was observed when $\mathrm{pH}$ of suspension was adjusted to 7 to 9 . Zeta potential of coagulants were raised by adding ultrasonic dispersion. High coagulation performance was obtained in site experiment, on the other hand, reduction of coagulants and effective dispersion method were desired for the practical use of volcanic ash coagulants.

Key Words: reservoir, turbid water, allophane, coagulation experiment, $p H$, zeta potential

\section{1.はじめに}

我が国ではこれまでにストックされた多くの貯水池を 時代のニーズに合わせて再生する取り組みが活発となっ ており，国土交通省においてもダム再生技術のPRと海 外展開を推進している1). 既設ダムの再開発あるいは放 流設備の増設などの改造工事を施工するには，貯水位を 低下させる操作が行われるが, 貯水池の末端部では流入 水が堆積土砂を巻き上げ，貯水池が懸濁化することが懸 念される. 一方, 貯水池の堆砂, ダム下流の河床材料の 粗粒化が課題となっている流域においては，水系単位で 土砂の移動を適切に管理する取り組みが始められている が ${ }^{2}$, 貯水池に堆積した土砂を湖内で移動する際にも， 㲘濁化一の対応が求められる. 貯水池の䀣濁化対策とし ては，流入河川の流路を固定して堆積土砂の巻き上げを 抑制する方法, 濁水フェンスを設置して濁質の流動を制 御する方法, 選択取水設備を運用して貯水池の表層部か ら下流に放流する方法などが挙げられるが，貯水池全体 が懸濁化した場合には，取り得る対策が限られるのが現
状である．貯水池の懸濁化への対応として凝集剤を用い た土粒子の強制沈降が考えられるが，一般に用いられる 人工の合成材料では, 貯水池底泥として長期滞留後の貯 水池の水質に与える影響が不明である. また, 沈降した 凝集フロックを別途処理する必要も生じることから，運 用実績はほとんど見あたらない.

本研究は，粘土鉱物アロフェンを主成分とした火山灰 土凝集剤を取り上げ，凝集・分散特性を明らかにすると ともに，貯水池濁水処理への適用について検討寸ること を目的とする，具体的には，「(1)火山灰土凝集剤の凝 集・分散と荷電特性」,「(2)火山灰土凝集剤を用いた貯 水池濁水処理」の2項目について報告する.

天然由来の粘土鉱物のうち，アロフェンおよびイモゴ ライトは比表面積が大きく凝集剤としての活用が考えら れる. 本報告では調達の容易さからアロフェンを主成分 とする火山灰土凝集剂を取り上げ，貯水池濁水処理への 適用について検討を進めた. 天然由来の粘土鉱物を凝集 剤とすることにより，凝集フロックを貯水池内の堆砂の 一部として捉えた貯水池管理が可能になると考えた. アロフェンとイモゴライトの特性の把握について，既 
往研究をレビューする，軽部らは，懸濁液中におけるア ロフェンとイモゴライトの分散凝集挙動と荷電特性を測 定し，脱鉄アロフェンでpH4.5〜 pH6，非脱鉄アロフェ ンでpH5.5〜 pH7の範囲で凝集が進行したと報じた ${ }^{3)}$. Adachiらは, pHの異なるアロフェン懸濁液の凝集実験を 行い，等電点（ゼータ電位が0となる点）付近において 速やかにフロック径が増加する状況を報告した4).

Tsuchidaらはイモゴライトを対象に異なるpH，イオン強 度の条件で凝集実験を行い，アルカリ領域で沈澱物の堆 積が増大すること，イモゴライトの荷電特性がチューブ 状の粒子形状を反映していることを報告した5).

一方, 火山灰土の凝集剤としての利用について, 堀岡 は，アロフェンに硫酸を添加することにより凝集性能を 高める方法を提案した6). 尾崎らは，火山灰土にpH調整 用を添加した凝集剤の製法を提案した7). しかしながら， 堀岡の研究は現地への適用にまでは言及しておらず，一 方，尾崎らの報告には凝集機構を具体的に説明する実験 結果が見あたらない．柏井らはアロフェンを主成分とす る火山灰土を材料とし，超音波分散，急速攪拌および緩 速攪拌の各処理を行うことにより，濁水を凝集処理でき ると報告した ${ }^{8)}$ ，筆者らは柏井らの研究を参考に，緩速 攪拌を行わずに凝集性能を高める方法を提案した9)。柏 井ら，筆者らの研究はいずれも室内実験に基づく報告で あった．本稿では既往研究を踏まえ火山灰土の凝集・分 散機構と荷電特性について詳述するとともに, 現地にて 凝集実験を行い，さらに，アロフェンを主成分とする火 山灰土凝集剤の現地適用性について検討寸る .

\section{2. 火山灰土凝集剤の凝集 - 分散と荷電特性}

\section{（1）火山灰土凝集剤の製造工程と化学成分}

本研究では，アロフェンを主成分とする火山灰土凝集 剂を使用した（表-1）。アロフェンは非結晶性のケイ酸 アルミニウム鉱物で，火山灰土䁃下層の主要なコロイド 粒子である. 火山国である日本では，北海道・東北・九 州を中心に全国に存在し，相当量の確保が期待できる ${ }^{8)}$. 水中に懸濁させたアロフェンは，周辺のpH環境により 凝集や分散現象を生じることが知られている ${ }^{3)}$,4).アロ フェンは，元来土壌中に含まれる物質であり，凝集剂と して貯水池に投入しても，水利用に及ぼす影響，生物生 息環境に及ぼす影響は少ないと考えられる。また，凝集 剤の添加による堆砂の増加量は微量であり, 貯水池の濁 水対策としての利用が期待されている.

火山灰土凝集剤の製造工程は，次の通りである.

1) 栃木県真岡市の採取地から火山灰土䁃を採取し，工 場に運搬.

2) 運搬した土壌に水を加え，木片などの不純物を除去.

3) 比重差を利用して主にアロフェンを含む土粒子を選 別して抽出し, 脱水.
表-1 火山灰土凝集剂の化学成分 ${ }^{10}$

\begin{tabular}{|c|c|c|c|c|c|}
\hline 成分 & $\mathrm{SiO}_{2}$ & $\mathrm{Al}_{2} \mathrm{O}_{3}$ & $\mathrm{Fe}_{2} \mathrm{O}_{3}$ & $\mathrm{CaO}$ & その他 \\
\hline 含有率[\%] & 50.0 & 43.2 & 3.6 & 1.1 & 2.1 \\
\hline
\end{tabular}

\section{（2）火山灰土凝集剤の凝集 · 分散}

本研究で取り扱う火山灰土凝集剤について基本的な性 状を把握することを目的に，異なるpH環境における凝 集・分散現象を把握する実験を行った。

\section{a) 実験方法}

目標とするpHは，3〜10の範囲に8段階設定した．本 実験ではpH環境を調整するために滴下する電解質の影 響を低減させるため, 懸濁液に $\mathrm{NaCl} を 0.01 \mathrm{M} の$ 濃度で 混合した。実験手順は，次の通りとした。

1) 乾燥重量 $0.9 \mathrm{~g}$ に相当する火山灰土凝集剤を取り分ける.

2) 純水約 $100 \mathrm{~mL}$ に火山灰土凝集剂を懸濁させる.

3) $\mathrm{NaCl} 0.1 \mathrm{M} 100 \mathrm{~mL}$ メンシリンダーに入れる.

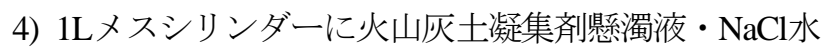
溶液・純水を加え，全体で1Lとする．濃度 $900 \mathrm{mg} / \mathrm{L}$ の火山灰土凝集剤懸濁液 $\mathrm{NaCl} 0.01 \mathrm{M}$ ができあがる.

5) 火山灰土凝集剤懸濁液をビーカーに取り分ける. 取 り分けたサンプルは, 約60mL.

6) マイクロピペットを用いて $\mathrm{HCl} 0.1 \mathrm{M}, \mathrm{NaOH} 0.1 \mathrm{M}$ 少量滴下し, pHを調整する. 調整中は, マグネット スターラーを用いて攪拌.

以上の手順で試料を作成した後, 静置して濁度の経時 変化を測定した。実験は，室温 $20^{\circ} \mathrm{Cl}$ 設定した恒温室内 で実施した．濁度の測定には，ホルマジン溶液により校 正した濁度計（HACH社製2100P）を使用した。

\section{b) 実験結果}

静置直後から120分経過までの濁度の経時変化を, 図一 1に示す. 濁度を測定した結果，pH 3.00の検体を除き， 凝集沈降が進行する結果となった。 $\mathrm{pH} 8.10$ の検体を例 に，濁度の経時変化を概観する. 静置直後に550 NTUの 濁度は時間の経過に伴い急速に低減する状況が観察され た. 静置後60分には14.6 NTUとなり，60分で濁度が約 1/38に低減した。 その後の濁度の低減は緩やかで, 120 分経過後の濁度は，8.99 NTUとなった．検体間で濁度の 差が比較的大きく現れた60分時点では， $\mathrm{pH} 7$ pH9の範 囲で特に凝集沈降が進行する結果となった。一方, $\mathrm{pH}$ 3.00の検体については，60分経過後の濁度が188 NTU, 120分経過後の濁度が97.8 NTUとなり, pH8.10の検体に 比べ10倍以上高い值を示し, 凝集沈降が進行しない結果 となった.

ここで，濁度の低減程度を示す無次元量として濁度比 $R_{T}$ を導入し, 異なる $\mathrm{pH} お け る 30$ 分経過後と60分経過 後のR $R_{T}$ を比較する（図-2）. 


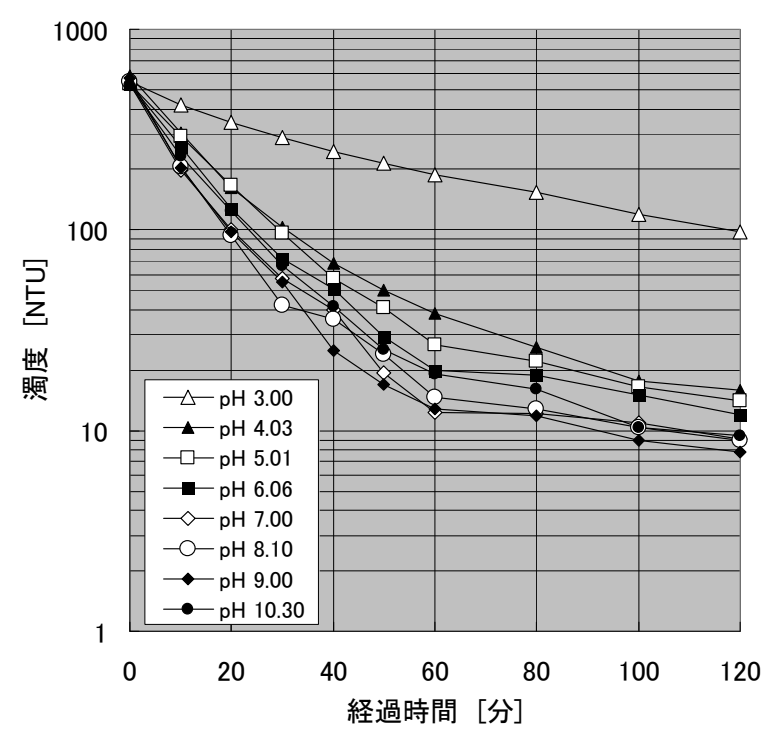

図-1火山灰土凝集剤懸濁液の濁度の経時変化 $(\mathrm{NaCl} 0.01 \mathrm{M})$

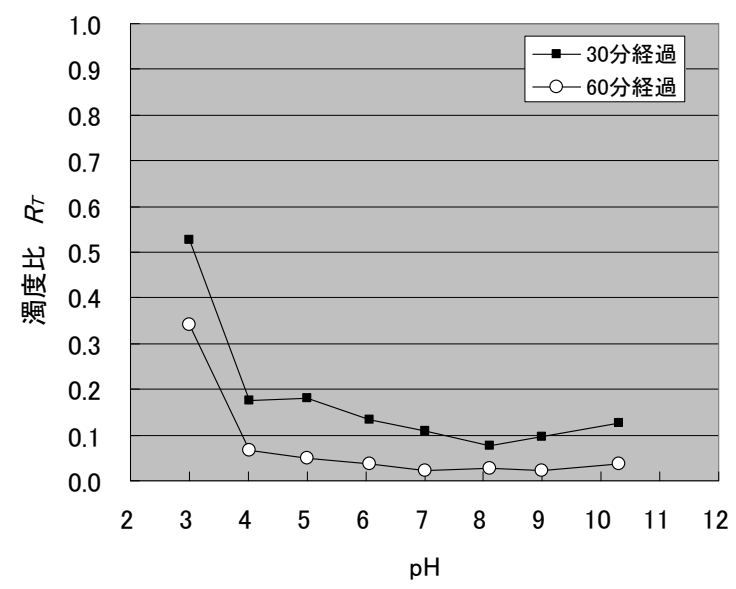

図-2 火山灰土凝集剂懸濁液のpHと濁度比 $(\mathrm{NaCl} \quad 0.01 \mathrm{M})$

$$
R_{T}=\frac{T_{n}}{T_{b}}
$$

ここに, $R_{T}$ : 濁度比 [無次元] $, T_{n}: \mathrm{n}$ 分静置後の濁度 $[N T U], T_{b}$ : 静置直後の濁度 $[N T U]$. 本研究で用いた アロフェンを主成分とする火山灰土凝集剤は, 軽部らの 報告3に比べ，アルカリ側を含む広い範囲で凝集沈降が 進行した結果となった.

\section{（3）火山灰土凝集剤の荷電特性}

アロフェン，イモゴライトなどのコロイド粒子は，周 辺の $\mathrm{pH}$ 環境により凝集や分散現象を生じることが知ら れている. 小林らはイモゴライトを取り上げ, $\mathrm{pH}$ 異 なる懸濁液中の凝集・分散挙動を報告した ${ }^{11)}, 12$ ， ここで は小林らの研究を参考に, $\mathrm{pH}$ 環境の異なる懸濁液中の 火山灰土凝集剤について, 電気泳動法により電気泳動移 動度を測定し，さらに，超音波分散の有無によるゼー夕 電位の差異について比較検討する.

\section{a） 実験方法}

濃度が900mg/Lとなるよう火山灰土凝集剤を純水中で 解きほぐし，塩濃度が0.01Mとなるよう $\mathrm{NaCl}$ を加え，火 山灰土凝集剤临濁液を作成した，次に，火山灰土凝集剤 懸濁液を2等分し，一方については，超音波を照射した。 超音波については, 出力 $60 \mathrm{~W}$, 周波数 $28 \mathrm{kHz}$ の装置を用 い，凝集剤懸濁液 $0.5 \mathrm{~L}$ に対し20分間照射した.さらに, 2種の懸濁液をそれぞれ8等分し，0.1MのHClあるいは $0.1 \mathrm{M}$ の NaOHを滴下し， $\mathrm{pH} 3 \sim \mathrm{pH} 10$ の懸濁液を8検体ず つ2組，計16検体作成した。 $\mathrm{HCl}$ また $\mathrm{NaCl}$ の滴下中は, マグネットスターラーを用いて攪拌し，各試料のpHが 容器内で均質となるよう留意した.

作成した各試料について，Malvern社製Zetasizer Nano ZSを用いて電気泳動移動度を測定し，ゼータ電位を算 定した. ゼータ電位の算定には, 次に示寸スモルコフス キー (Smoluchowski) の式苂を用いた.

$$
\mu=\frac{\varepsilon_{r} \varepsilon_{0}}{\eta} \zeta
$$

ここに, $\mu$ : 電気泳動移動度 $\left[\mathrm{m}^{2} / \mathrm{V} \cdot \mathrm{s}\right], \varepsilon_{r}$ : 媒体の比 誘電率 [無次元] $\left(20^{\circ} \mathrm{C}\right.$ 水の場合80.4 $), \varepsilon_{0}$ : 真空の誘 電率 $[\mathrm{F} / \mathrm{m}]\left(=8.854 \times 10^{-12}\right), \zeta$ : ゼー夕電位 $[\mathrm{V}], \eta$ : 媒体の粘性係数 $[\mathrm{Pa} \cdot \mathrm{s}]\left(20^{\circ} \mathrm{C}\right.$ の水の場合 $\left.1.002 \times 10^{-3}\right)$.

\section{b) 実験結果}

電気泳動移動度の測定結果をもとに，算出したゼー夕 電位を図-3に示す．超音波分散を加えない試料のゼータ 電位はpH $<7$ で正の値, また, $\mathrm{pH}>9$ で負の值を示し た. また, 同じpHの検体について比較すると, 超音波 分散を加えることによりゼータ電位が正の方向に移動し た. この傾向は, $\mathrm{pH}<7$ で顕著に表れ，pH $>9$ では差 異が縮まる結果となった。これは超音波を照射すること により火山灰土凝集剤のフロックが破壊され，各粒子が 分散媒と接する面積が増大したことに起因すると考えら れる.

ダム貯水池の懸濁化の原因となる微細な土粒子の多く は，負に帯電している. ダム貯水池のpH環境として一 般的なpH7近傍では，火山灰土凝集剂に超音波分散を加 えることにより電位が $3.3 \mathrm{mV}(\mathrm{pH} 7.00)$ から $17.4 \mathrm{mV}$ (pH6.94) に高まった。 火山灰土凝集剤を用いた貯水池濁 水処理については後述するが，超音波を照射することに より凝集剤が分散し，その結果として土粒子を吸着する 能力が高まることが期待された.

なお，本研究で使用した火山灰土凝集剂の等電点は 「超音波分散なし」の試料でpH8付近となり，軽部らの 報告3)にあるpH5.1（脱鉄試料）あるいはpH5.9（非脱鉄 試料）よりもアルカリ側に位置する. また，凝集実験で は, アルカリ側を含む広い範囲で凝集沈降が進行した. これは, 本研究で用いた火山灰土凝集剂の原料の採取地 (杤木県真岡市) が軽部らの報告にある採取地（杤木県 鹿沼市）と異なること, 本研究で用いた火山灰土凝集剂 には，主成分とされる $\mathrm{SiO}_{2}, \mathrm{Al}_{2} \mathrm{O}_{3}$ 以外にも $\mathrm{Fe}_{2} \mathrm{O}_{3}, \mathrm{CaO}$ 
などの化学成分が $6.8 \%$ 含まれ，例えば，Fe，Caなどの 成分が懸濁液中で正電荷を発現したこと，本凝集剂は， アロフェンを主成分としつつもかなりの量のイモゴライ トが混合し，その結果として等電点がpHの高い方向に 移動した見られることなどが理由として考えられる. な お，小林らは，イモゴライトの等電点をpH9付近とし， アロフェンに比べ，イモゴライトの等電点を与える $\mathrm{pH}$ が高いことを報告している ${ }^{11), 12) . ~}$

火山灰土凝集剤の「超音波分散なし」試料のゼー夕電 位と (2) で求めた 30 分経過後, 60 分経過後の濁度比 $R_{T}$ を まとめ, 図-4に示す.

ここで, ゼータ電位が0に近い検体については凝集が 進行することを容易に説明できるが， $-22 \mathrm{mV} 〜 23 \mathrm{mV}$ の 検体についても30分経過後に $R_{T}<0.2,60$ 分経過後には $R_{T}<0.1$ となり, 凝集が相当程度進行する結果となった. これは, 火山灰土凝集剤眵濁液の塩分濃度を $0.01 \mathrm{M}$ に調 整した結果電解質濃度が高まり, 粒子を取り巻く電気二 重層が圧縮され静電的反発力が弱まり, 分子間力が卓越 して凝集が進行したものと考えられる

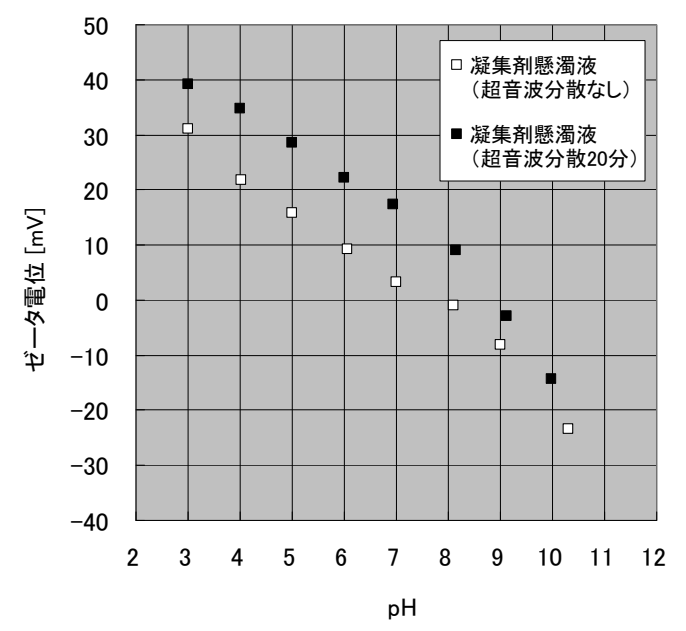

図-3 火山灰土凝集剂䯚濁液のpHとゼ一タ電位 $(\mathrm{NaCl} \quad 0.01 \mathrm{M})$

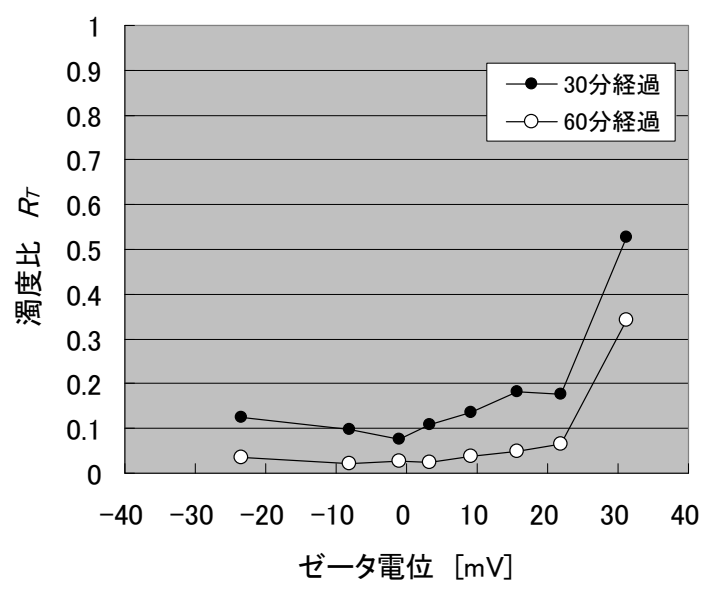

図-4火山灰土凝集剤懸濁液のゼ一夕電位と濁度比 $(\mathrm{NaCl} 0.01 \mathrm{M})$

\section{3. 貯水池濁水処理への適用}

本章では，山須原ダム貯水池（九州電力（株）管理） をサイトに実施した現地実験について報告する．さらに， 火山灰土凝集剂を用いた貯水池濁水処理の実用化に向け た課題を整理する．耳川水系に位置する3ダムでは，貯 水池に堆積した土砂の移動と出水時の通砂運用を目指し た放流設備の改造が行われている ${ }^{15)}$ ，なお，現地実験の 結果については一部文献16)で報告済みであるが，今般， 実験に用いた濁水の特性に関するデータを追記し，凝集 処理の効果について再評価し報告する.

\section{（1）実験方法}

山須原ダムでは, 貯水池に堆積した土砂を湖内移動す る試験工事が実施されている。現地実験では，堆積した 土砂を陸揚げした際に生じる濁水を, 湖岸に設置した2

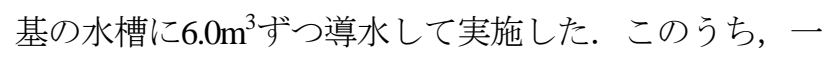
方の水槽は凝集処理を行い（水槽1），他方の水槽は何 ら処理を行わず，そのまま静置した（水槽2）。現地実 験は，2012年2月に実施した. 実験中の濁水の水温は, 水槽の上層部で $8.9 \sim 1.3^{\circ} \mathrm{C}$ 範囲で, また, 下層部で $8.0^{\circ} \mathrm{C} \sim 4.0^{\circ} \mathrm{C}$ 範囲で変化した. 凝集処理の手順は次の 通りとした.

\section{a）凝集剂懸濁液の作成}

凝集剂投入量に関する予備実験の結果を基に ${ }^{16)}$ ，濁度 285〜290 NTUの濁水に対して凝集剂投入量を450mg/Lに 設定し, 乾燥重量に換算して $2.7 \mathrm{~kg}$ の湿潤凝集剤を準備 した. 次に，湿潤凝集剤を少量の濁水に混ぜ合わせ，家 庭用ミキサーでペースト状に混合した. ここで, ペース 卜状の凝集剤を直接水槽1に投入した場合, 濁水と凝集 剤とが混合せずに凝集剤のみ沈殿することも考えられる ことから，凝集剤をタンクに移し， $0.5 \mathrm{~m}^{3}$ の濁水と混合 して凝集剂懸濁液を作成した。凝集剂览濁液の作成に濁 水を用いたのは, 両水槽の試料の均質性を保つためであ る.

\section{b）超音波分散十攪拌}

凝集剂览濁液 $0.5 \mathrm{~m}^{3}$ をンンクから水槽に移し, $5.5 \mathrm{~m}^{3}$ の 濁水と混合し, 凝集㓮・濁水混合液を作成した. 次に, 周波数 $20 \mathrm{kHz}$ ，出力 $600 \mathrm{~W}$ の超音波分散装置を用いて180 分間超音波分散した. 分散時間は体積 $3.98 \mathrm{~m}^{3}$ の濁水を対 象とした先行実験において効果の見られた実験ケースを 参考に設定した．ここで，超音波は水面付近から照射し， 効果が及ぶ範囲も限定されると考えられる. そこで, 吸 水量13L/分の水中ポンプ4台を併用し, 凝集㶡による濁 質の吸着が進行するよう，水槽内を攪拌した（図-5）. 以上の手順を経た後に静置し，2基の水槽の上層部，下 層部それぞれについて濁度の経時変化を測定した，濁度 の測定には，ホルマジン溶液により校正した多項目水質 計（東亜ディーケーケー社製WQC-24）を使用した. 


\section{c) 試料分析}

無処理のまま静置する水槽2より濁水を取り分け，SS を測定するとともに，試料を希勫して濁度を測定し，濁 度とSSの関係を整理した．また，濁水を構成する土粒子 のゼータ電位ならびに粒度分布を測定した．ゼータ電位 と粒度分布については，超音波分散した試料としない試 料の両方について測定した. ゼータ電位の測定には, Malvern社製Zetasizer Nano ZSを用いた．粒度分布の測定 には，島津製作所製SALD 2300を使用した。

\section{（2）実験結果}

凝集処理した水槽1，無処理のまま静置した水槽2につ いて，濁度の経時変化を測定した結果を，図-6に示す。 ここで，超音波分散・攪汼開始時刻を-180分，超音波分 散・攪拌終了時刻を0分とし，-180分から1440分までの 濁度の経時変化を整理した.

超音波分散・攪拌開始時の濁度は，水槽1の上層・下

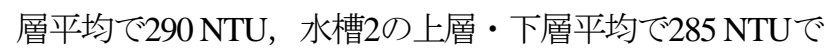
あったが，水槽1，水槽2とも時間の経過とともに濁度が 低減した. 特に，凝集処理をした水槽1では，凝集処理 中にもフロックの形成が目視で確認され, 濁度が大きく 低減した. 実験の前半で，上層の濁度が下層より大きい 数值を示したが，これは強風により水面付近が擋乱され， 水槽上層部では土粒子の沈降が妨げられた一方，下層部 では土粒子が順調に沈降したためたためと考えられる. また，実験の後半で水槽1の下層部に濁度の上昇が見ら れるが，これは，水温が低下寸る過程で対流が生じ，一 旦沈降したフロックが再浮上したためと考えられる. 1440分後の濁度は凝集処理した水槽1の上層・下層平均 で13.6 NTU，無処理である水槽2の上層・下層平均で186 NTUとなり，アロフェンを主成分とする火山灰土凝集剤 による凝集効果が現地実験においても確認された.

現地実験で用いた濁水の特性について，整理する（表 -2，図-7）。山須原ダムから採取した濁水は濁度290 NTU に対LSS $200 \mathrm{mg} / \mathrm{L}$ となり, SSは濁度の2/3程度の 值を示した. 現地実験では凝集剤を450 mg/Lに設定した

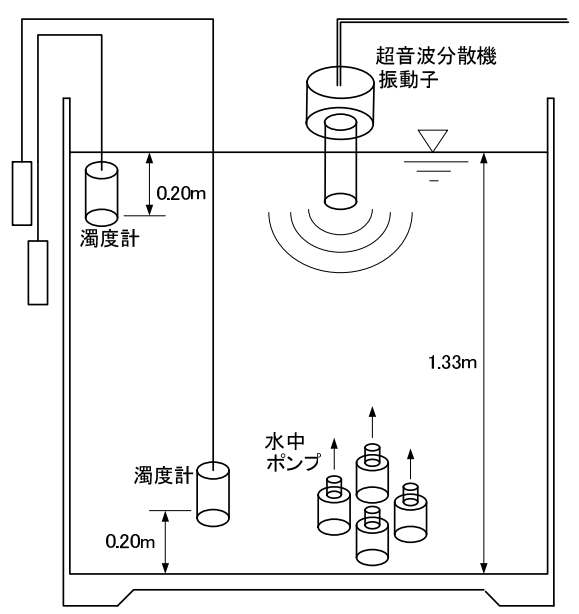

図-5 現地実験の機器

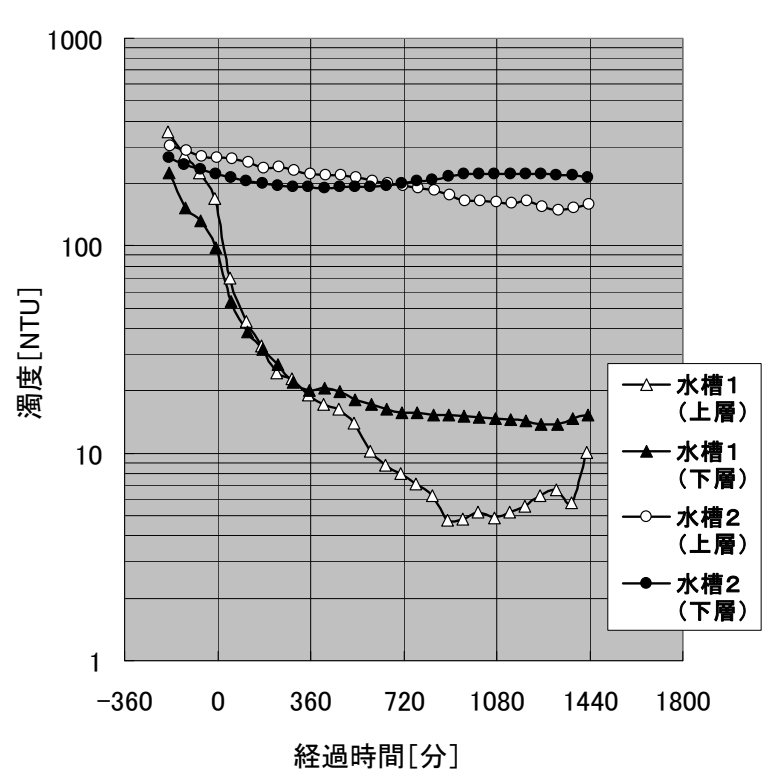

図-6 濁度の経時変化（現地実験）

表-2＼cjkstart試料の濁度·SS·pH·ゼ一夕電位

\begin{tabular}{|c|c|c|c|c|c|}
\hline \multirow[b]{2}{*}{ 採水地 } & \multirow[b]{2}{*}{$\begin{array}{c}\text { 濁度 } \\
\text { [NTU] }\end{array}$} & \multirow[b]{2}{*}{$\begin{array}{c}\mathrm{SS} \\
{[\mathrm{mg} / \mathrm{L}]}\end{array}$} & \multirow[b]{2}{*}{$\mathrm{pH}$} & \multicolumn{2}{|c|}{ ゼータ電位 } \\
\hline & & & & $\begin{array}{c}\text { 分散なし } \\
{[\mathrm{mV}]}\end{array}$ & $\begin{array}{c}\text { 分散15min } \\
{[\mathrm{mV}]}\end{array}$ \\
\hline $\begin{array}{l}\text { 山須原 } \\
\text { ダム }\end{array}$ & 290 & 200 & 7.36 & -23.1 & -2 \\
\hline
\end{tabular}

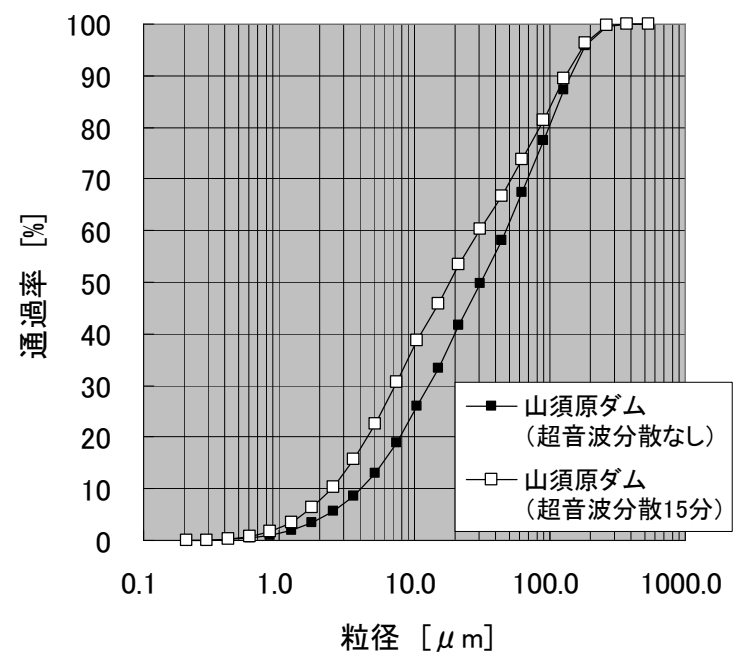

図-7＼cjkstart試料の粒度分布

たことから，濁水のSSに対して2.25倍の濃度で㠜集剤を 投入したことになる. 山須原ダムのpHは7.36であり，ほ ぼ中性の值を示した. ゼータ電位は-23.1〜-23.4 mV で あり，超音波分散の有無でほとんど変化しなかった．粒 度については，粒径10 $\mu \mathrm{m}$ 以下の粒子の占める割合が超 音波分散なしの試料で $25 \%$ ，超音波分散15分の試料で 38\%となった．濁水には多くの細粒分が含まれ，無処理 の水槽2における濁度の緩やかな低減を裏付けた。一方, 処理した水槽1において凝集効果が現れた理由としては, 
濁水のゼー夕電位の絶対值が高く，超音波分散により正 電荷を増した凝集剂との荷電中和が進行したことが考え られた。

火山灰土凝集剂の貯水池濁水処理への適用について課 題を整理する．現地実験では濁度285〜290NTUの原水に 対して450mg/Lの濃度で凝集剤を投入した。濁水のSSに 対する凝集㶡の濃度は2.25倍であり, 凝集剤投入量の縮 減が課題として挙げられる。.また，現地実験では凝集剂 を濁水と混合後に分散した。凝集剤を濁水と混合寸る前 に分散処理し，濁水との混合後まで凝集剂の分散状態が 持続するような分散処理手法の開発が課題として挙げら れる.

\section{4. まとめ}

本報告は，アロフェンを主成分とする火山灰土凝集剤 を取り上げ，凝集・分散特性を明らかにするとともに， 貯水池濁水処理への適用について検討したものである. 結論を以下にまとめる.

- 異なる $\mathrm{pH}$ 環境において火山灰土凝集剤の凝集・分散 現象を把握した結果， $\mathrm{pH} 7$ pH9の範囲で特に凝集が 進行した.

$\cdot \mathrm{pH}$ 環境の異なる䀣濁液中の火山灰土凝集剤について, 電気泳動移動度を測定した結果, $\mathrm{pH}<7$ で正の值, また, $\mathrm{pH}>9$ で負の值を示した. 火山灰土凝集剂は, アロフェンを主成分としつつもかなりの量のイモゴ ライトが混合し，その結果として等電点が $\mathrm{pH}$ の高い 方向に移動したと考えられた.

・超音波分散の有無によるゼー夕電位の差異について比 較したところ，超音波分散を加えることによりゼータ 電位が正の方向に高まった．これは超音波を照射する ことにより火山灰土凝集剤のフロックが破壊され，各 粒子が分散媒と接する面積が増大したことに起因する と考えられた.

・貯水池の䀣濁化対策として火山灰土凝集剂を用いた現 地実験を実施した. 濁度 285～290 NTU の濁水に対し 凝集剂投入量を $450 \mathrm{mg} / \mathrm{L}$ に設定して凝集処理した結 果, 1440 分後の濁度は処理水槽の平均で 13.6 NTU, 無処理水槽の平均で 186 NTU となり，火山灰土凝集 剂による凝集効果が現地実験において確認された。

・現地実験で凝集効果が現れた理由としては, 濁水の ゼータ電位の絶対值が高く, 超音波分散により正電荷 を増した凝集剤との間で荷電中和が進行したことが考 えられた。

・今後の実用化に向けた課題として, 凝集剂投入量の縮 減と凝集剤の分散処理手法の開発が挙げられた.

謝辞 : 本研究を実施するにあたり，現地での実験場所の 確保と資機材の貸与等で宮崎県河川課ならびに九州電力
（株）耳川水力整備事務所の方々にご協力頂きました. また，実験結果をまとめるにあたり，筑波大学大学院足 立泰久教授, 入江光輝准教授より, 貴重な助言をいただ きました。ここに，御礼申し上げます。

\section{参考文献}

1) 国土交通省パンフレット : Advanced Technologies to Upgrade Dams under Operation, 2013.

2) 宮崎県 : 耳川水系総合土砂管理計画, 2011.

3) 軽部重太郎, 杉本英夫, 藤平雅巳, 中石克也 : アロフェンと イモゴライトの分散凝集と荷電特性, 農業土木学会論文集, No.196, pp.103-110, 1998.

4) Y. Adachi, S. Koga, M. Kobayashi and M. Inada: Study of colloidal stability of allophane dispersion by dynamic light scattering, Colloids and Surfaces A, No.265, pp.149-154, 2005.

5) H. Tsuchida, S. Ooi, K. Nakaishi, and Y. Adachi: Effects of pH and ionic strength on electrokinetic properties of imogolirte, Colloids and Surfaces A, No.265, pp.131-134, 2005.

6) 堀岡正和: 新しい凝集剂に関する研究（I）ーアロフェンを 原料とする凝集剤の製法一, 水道協会雑誌, 第398号, pp.916, 1967.

7) 尾崎哲二, 口舩愛, 森本辰雄, 和田信一郎 : 火山灰土を原料 とする新しい凝集剤の開発, 土木学会誌, Vol.93, No.6, pp.52-55, 2008.

8) 柏井条介, 結城和宏 : 天然凝集材（アロフェン）の濁質凝集 効果，ダム技術，No.239, pp.20-28, 2006.

9) 海野仁，箱石憲昭 : 天然由来の凝集剤を用いた貯水池濁水処 理における凝集特性の評価, 土木学会論文集B1（水工学） Vol.68, No.4, I_919-I_924, 2012.

10) 品川化成（株）WEBページ http://www.shinagawa.co.jp 11) 小林幹佳, 似内美貴, 大内岳, 高橋政之輔, 颯田尚哉, 足立泰久 : モデルコロイドの凝集沈降実験に基づく天然粘土 鉱物イモゴライトの濁水凝集機構, 土木学会論文集B1（水 工学)，Vol.68, No.4, I_787-I_792, 2012.

12) M. Kobayashi, M. Nitanai, N. Satta and Y. Adachi: Coagulation and charging of latex particles in the presence of imogolite, Colloids and Surfaces A, No.435, pp.139-146, 2013.

13) 例えば, 近藤保, 大島広行, 村松延弘, 牧野公子 : 生物物 理化学, pp.94-95, 三共出版, 1992.

14) 大井節男 : コロイド現象の物理的基礎，土のコロイド現象, pp.85-91, 学会出版センター, 2003.

15) Y. Yamagami, M. Kaku, K. Asazaki and Y. Tashiro: Approaches for Integrated Flow Management at Dams in the Mimikawa River Basin, International Symposium on Dams for a Changing World, ICOLD Kyoto, pp.2_143-2_148, 2012.

16) 海野仁，箱石憲昭 : 天然凝集材を用いた濁水凝集処理に関 する現地実験, 土木学会第68回年次学術講演会概要集第 II 部 門, pp.201-202, 2013.

(2013. 9. 30受付) 